\title{
Proses Kognitif Mahasiswa Calon Guru Matematika Melalui Penerapan Metode Kooperatif Tipe Guided Note Taking
}

\author{
Yuntawati ${ }^{1}$, Sanapiah ${ }^{2}$, Lalu Abdul Aziz \\ ${ }^{1,2}$ Pendidikan Matematika FSTT Universitas Pendidikan Mandalika \\ ${ }^{3}$ PGSD Fakultas Pendidikan UNU-NTB
}

Email: yuntawati@undikma.ac.id

\begin{abstract}
The purpose of this study was to determine how the cognitive processes of prospective mathematics teacher students through the application of the Guided Note Taking method. The subjects of this study were the fifth semester students of the Mathematics Education Study Program, FSTT UNDIKMA. This type of research is descriptive analysis. Data collection techniques used are assignment and observation. The data analysis of this research describes each cognitive learning process starting from the process of acquiring new information, transforming the information received, and testing or developing the relevance and accuracy of knowledge. Based on the exposure of the research data, it can be said that the fifth semester students of the Mathematics Education Study Program are in the category or highest cognitive level, namely those who are able to absorb information and process it to the limit of application. Meanwhile, in cognitive processes, students are able to obtain information and information received, but have not been able to test and develop the relevance or accuracy of their knowledge.
\end{abstract}

Keywords: cognitive processes, Guided Note Taking

\begin{abstract}
Abstrak: Tujuan penelitian ini untuk mengetahui bagaimana proses kognitif mahasiswa calon guru matematika melalui penerapan metode Guided Note Taking. Subyek penelitian ini adalah mahasiswa semester V Program Studi Pendidikan Matematika FSTT UNDIKMA. Jenis penelitian ini adalah analisis deskriptif. Teknik pengumpulan data yang digunakan adalah penugasan dan observasi. Analisis data penelitian ini dengan mendeskripsikan setiap proses kognitif mahasiswa diawali dari proses perolehan informasi baru, transformasi informasi yang diterima, dan menguji atau mengevaluasi relevansi dan ketepatan pengetahuan. Berdasarkan paparan data hasil penelitian dapat disimpulkan bahwa mahasiswa semester V Prodi Pendidikan Matematika masuk dalam kategori atau tingkat kognitif level tertinggi yaitu applying yang artinya mahasiswa mampu menyerap informasi dan mengolahnya sampai pada batas pengaplikasian. Sedangkan pada proses kognitif mahasiswa mampu memperoleh informasi dan mentransformasi informasi yang diterima, tetapi belum mampu menguji dan mengevaluasi relevansi atau ketepatan pengetahuannya.
\end{abstract}

Kata kunci: proses kognitif, Guided Note Taking

\section{PENDAHULUAN}

Istilah kognitif sangat popular sebagai salah satu wilayah psikologi manusia atau suatu konsep umum yang mencakup semua bentuk pengenalan. Hal ini meliputi setiap perilaku mental yang berhubungan dengan masalah pemahaman, memperhatikan, memberikan, menyangka, pertimbangan, pengolahan informasi, pemecahan masalah, membayangkan, memperkirakan, berpikir, dan keyakinan. Perkembangan kognitif yang digambarkan Piaget merupakan proses adaptasi intelektual. Adaptasi ini merupakan proses yang melibatkan skemata, asimilasi, akomodasi, dan equilibrasi. Skemata adalah struktur kognitif yang berupa ide, gagasan, konsep. Asimilasi adalah proses perubahan apa yang dipahami sesuai dengan struktur kognitif (skemata) yang ada sekarang. Akomodasi adalah proses penyesuaian struktur 
kognitif kedalam situasi baru. Equilibrasi adalah pengaturan diri secara mekanis untuk mengatur keseimbangan proses asimilasi dan akomodasi.

Teori kognitif terus dikembangkan oleh para ahli tidak hanya dalam proses perkembangan individu tapi juga dalam tahapan pembelajaran. Menurut Jerome S. Bruner, seorang ahli psikologi kognitif, pada dasarnya belajar adalah proses kognitif yang terjadi dalam diri seseorang, yang meliputi: a) Proses perolehan informasi baru, b) Proses transformasi informasi yang diterima, c) Proses menguji atau mengevaluasi relevansi dan ketepatan pengetahuan (Sutarto, 2017). Informasi baru diperoleh dengan cara membaca buku, mendengarkan penjelasan guru, mendengarkan dan melihat informasi melalui media audio visual, dan lain-lain. Makna lain dari proses transformasi adalah tahap memahami, mencerna, dan menganalisis pengetahuan baru yang selanjutnya mengubah dalam benrtuk baru yang dapat dimanfaatkan untuk hal-hal yang lain. Misalnya, pengetahuan/informasi yang diperoleh dari satu referensi, dapat diaplikasikan di referensi lain dalam bentuk yang berbeda. Proses berikutnya adalah menguji dan mengevaluasi relevansi dan ketepatan pengetahuan/informasi yang diterima. Jadi dapat dikatakan bahwa proses kognitif adalah proses berpikir atau proses mengolah informasi baru di dalam memori untuk dicerna dan dipahami menjadi sebuah pengetahuan.

Peningkatan proses kognitif dapat dilakukan melalui pembelajaran kooperatif yang memungkinkan peserta didik bekerjasama, berkomunikasi memecahkan masalah. Komunikasi dan kerjasama yang baik dalam pembelajaran kooperatif dapat membantu peserta didik dalam mengidentifikasi masalah, dan memikirkan solusi pemecahan masalah. Pembelajaran kooperatif menciptakan kerjasama dan komunikasi yang mempengaruhi proses kognitif peserta didik. Menurut Piaget bahwa dalam tahap pengembangan proses kognitif, interaksi secara terus menerus dengan lingkungan dapat membentuk pengetahuan peserta didik (Dimyati \& Muljiono, 2006).

Penelitian tentang penerapan pembelajaran kooperatif telah banyak dilakukan. Berdasarkan hasil penelitian, pembelajaran kooperatif dapat meningkatkan kemampuan kognitif (Oktafiani, 2017; Sari \& Suarni, 2020; Lestari et al., 2021), motivasi dan hasil belajar (Kabunggul et al., 2020; Kusmaniar, 2019; Utami, 2015), dan kemandirian (Gusnita et al., 2021; Syaharani, 2018; Utami, 2015). Pemilihan metode dalam pembelajaran kooperatif sangat dipengaruhi oleh karakteristik peserta didik dan lingkungan belajar. Mahasiswa semester V Program Studi Pendidikan Matematika Fakultas Sain, Teknik, dan Terapan Universitas Pendidikan Mandalika mempunyai kemampuan komunikasi yang cukup interaktif. Hal ini terlihat dari keakraban dan interaksi mahasiswa yang sangat baik di luar kelas. Akan tetapi, hal ini berbeda jika di dalam kelas pada proses pembelajaran. Kelancaran berkomunikasi, mengeluarkan pendapat, dan bertanya tidak nampak. Mereka cenderung pasif, tidak ada yang bertanya ketika diberi kesempatan bertanya dan tidak bisa menjawab ketika diberi pertanyaan. Salah satu metode pembelajaran yang sesuai diterapkan pada mahasiswa dengan karakteristik seperti ini adalah metode pembelajaran kooperatif tipe Guided Note Taking.

Metode Guided Note Taking atau disebut juga catatan terbimbing adalah metode pembelajaran yang menggunakan suatu bagan, skema (handout) ((Aprianti, 2017), gambar atau alat peraga ((Hidayat \& Utami, 2020) sebagai media siswa membuat catatan hal-hal yang paling penting saat guru menyampaikan materi. Penerapan metode Guided Note Taking pada penelitian ini mahasiswa tidak diberikan handout, bagan, skema, gambar ataupun alat peraga, akan tetapi mahasiswa diminta membuat sendiri handout yang berisi resume/rangkuman materi yang mereka telusuri sendiri. Selanjutnya mahasiswa saling menukar rangkuman secara acak dan 
membubuhkan catatan penting, berupa pernyataan ataupun pertanyaan yang dapat memfokuskan pada materi. Pertanyaan-pertanyaan yang dibuat dapat menumbuhkan rasa penasaran mahasiswa untuk terus mencari informasi yang diinginkan dan dapat menggali pengetahuan baru dalam forum diskusi melalui pembelajaran kooperatif. Penerapan metode Guided Note Taking ini sekaligus dapat menumbuhkan rasa percaya diri mahasiswa untuk aktif mengajukan pendapat, saran, maupun pertanyaan tentang materi yang dipelajari dan keinginan untuk terus menambah pengetahuan. Hal ini dengan sendirinya akan membawa dampak positif pada hasil belajar mahasiswa.

Tujuan dari penelitian ini adalah untuk mengetahui bagaimana proses kognitif mahasiswa calon guru matematika melalui penerapan metode Guided Note Taking. Sehingga selanjutnya dosen atau pengampu mata kuliah dapat mempersiapkan bahan ajar yang dapat disesuaikan dengan tingkatan proses kognitif mahasiswa.

\section{METODE}

Subyek penelitian ini adalah mahasiswa semester V Program Studi Pendidikan Matematika Fakultas Sain, Teknik, dan Terapan Universitas Pendidikan Mandalika. Jenis penelitian ini adalah analisis deskriptif yaitu mendeskripsikan data dengan apa adanya. Teknik pengumpulan data dalam penelitian ini adalah melalui penugasan dan observasi. Mahasiswa diberi tugas membuat rangkuman materi Ruang Dimensi Tiga yaitu salah satu materi pada mata kuliah Kalkulus Peubah Banyak. Selanjutnya mahasiswa saling menukar rangkuman secara acak, membaca, memahami, dan membubuhkan catatan penting, berupa pernyataan ataupun pertanyaan yang dapat memfokuskan pada materi. Analisis data penelitian ini dengan mendeskripsikan setiap proses kognitif mahasiswa diawali dari proses perolehan informasi baru, transformasi informasi yang diterima, dan menguji atau mengevaluasi relevansi dan ketepatan pengetahuan.

Adapun tingkatan atau level kognitif mahasiswa pada tiap proses kognitifnya berpedoman pada tabel 1 berikut.

Tabel 1. Tingkatan atau level kognitif mahasiswa pada tiap proses kognitif

\begin{tabular}{|c|c|}
\hline Proses Kognitif & Tingkatan/Level Kognitif \\
\hline Proses Perolehan Informasi & Knowing \\
\hline Baru & $\begin{array}{l}\text { Mahasiswa memiliki kemampuan standar } \\
\text { minimum dalam menguasai pelajaran } \\
\text { - Mahasiswa mampu membuat generalisasi } \\
\text { sederhana } \\
\text { - Mahasiswa mampu mengkomunikasikan } \\
\text { informasi yang diperoleh dalam bentuk lisan } \\
\text { maupun tulisan }\end{array}$ \\
\hline $\begin{array}{l}\text { Proses transformasi } \\
\text { informasi yang diterima }\end{array}$ & $\begin{array}{l}\text { Applying } \\
\text { Mahasiswa memiliki kemampuan aplikatif } \\
\text { - Mahasiswa mampu memperlihatkan } \\
\text { pengetahuan dan pemahaman dengan } \\
\text { membuat komentar penting pada rangkuman } \\
\text { mahasiswa lain } \\
\text { - Mahasiswa mampu menginterpretasi dan } \\
\text { menganalisis informasi dan data } \\
\text { - Mahasiswa mampu mengintepretasi grafik, } \\
\text { tabel, dan materi visual lainnya }\end{array}$ \\
\hline $\begin{array}{l}\text { Proses menguji atau } \\
\text { mengevaluasi relevansi dan }\end{array}$ & $\begin{array}{l}\text { Reasoning } \\
\text { Mahasiswa memiliki kemampuan penalaran dan } \\
\text { logika }\end{array}$ \\
\hline
\end{tabular}




\begin{tabular}{ll}
\hline ketepatan pengetahuan & Mahasiswa mampu menjelaskan hubungan \\
& konseptual dan informasi yang faktual \\
- & Mahasiswa mampu memecahkan masalah \\
& dengan berbagai cara dan melibatkan banyak \\
& variable \\
- & Menganalisis, mensintesis, dan \\
mengevaluasi gagasan dan informasi yang \\
faktual
\end{tabular}

\section{HASIL DAN PEMBAHASAN}

Proses kognitif yang diusung oleh Jerome S. Bruner ini merupakan proses pengolahan informasi sampai menjadi sebuah pengetahuan. Dalam prosesnya, proses kognitif melibatkan tiga komponen utama yaitu Sensory Memory, Working Memory, dan Long Term Memory (Salsabila, 2017). Proses pengolahan informasi dalam proses kognitif digambarkan pada gambar 1 berikut.

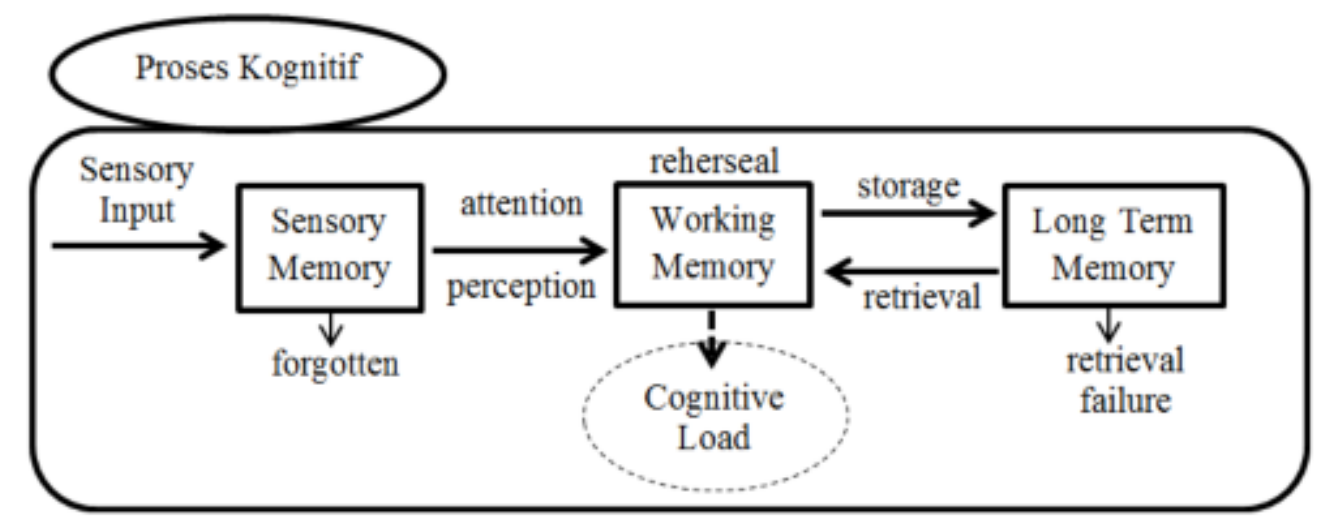

Gambar 1. Proses pengolahan informasi dalam proses kognitif

Berdasarkan observasi peneliti terhadap tugas yang dikumpulkan mahasiswa yaitu berupa rangkuman materi Ruang Dimensi Tiga yang merupakan salah satu materi pada mata kuliah Kalkulus Peubah Banyak diperoleh data bahwa sebagian besar mahasiswa menyelesaikan tugasnya dengan baik. Cakupan materi yang disajikan dalam rangkuman cukup lengkap mulai dari pengertian ruang dimensi tiga, grafik persamaan, dan vektor dalam ruang dimensi tiga. Hal ini menunjukkan bahwa mahasiswa mampu memperoleh atau menyerap informasi baru dan menuangkan dengan baik informasi yang diperoleh dari berbagai sumber yang mereka cari kedalam bentuk tulisan. Pada tingkatan ini mahasiswa berada pada level mengetahui (knowing) dimana mahasiswa memiliki kemampuan standar minimum dalam menguasai materi. Dalam teorinya, informasi yang diperoleh mahasiswa diterima partama kali oleh Sensory Memory dan terjadi tiga proses didalamya yaitu perhatian, persepsi dan pemberian makna. Informasi yang secara sadar ataupun tidak sadar diperhatikan akan dipersepsikan sesuai dengan pengetahuan awal mahasiswa dan selanjutnya dikirim ke Working Memory untuk dimaknai. Oleh karena itu pengetahuan awal mahasiswa sangat mempengaruhi proses persepsi ini. Yuntawati \& Aziz, (2017) menjelaskan pentingnya pengetahuan awal siswa dalam memulai pembelajaran karena dapat meningkatkan minat atau ketertarikan siswa terhadap materi yang diajarkan. 
Selanjutnya mahasiswa saling menukar rangkuman secara acak, membaca, memahami, dan membubuhkan catatan penting, berupa pernyataan ataupun pertanyaan yang dapat memfokuskan pada materi. Kosko \& Wilkins (2010) menyatakan bahwa menulis yang bias direpresentasikan dalam bentuk catatan penting berupa pernyataan atau pertanyaan merupakan salah satu cara merefleksikan ide-ide matematika secara detail. Dari hasil analisis, terlihat mahasiswa sudah mampu menuangkan ide/gagasan/saran dan pertanyaan-pertanyaan kritis yang cukup bermakna dan sesuai dengan konsep yang dipaparkan. Hal ini menunjukkan bahwa mahasiswa mampu mentransformasi atau memahami, mencerna, dan menganalisis pengetahuan baru yang selanjutnya mengubah dalam benrtuk baru yang dapat dimanfaatkan untuk hal-hal yang lain. Proses transpormasi informasi yang diterima digambarkan dalam hasil kinerja mahasiswa pada gambar 2 berikut.

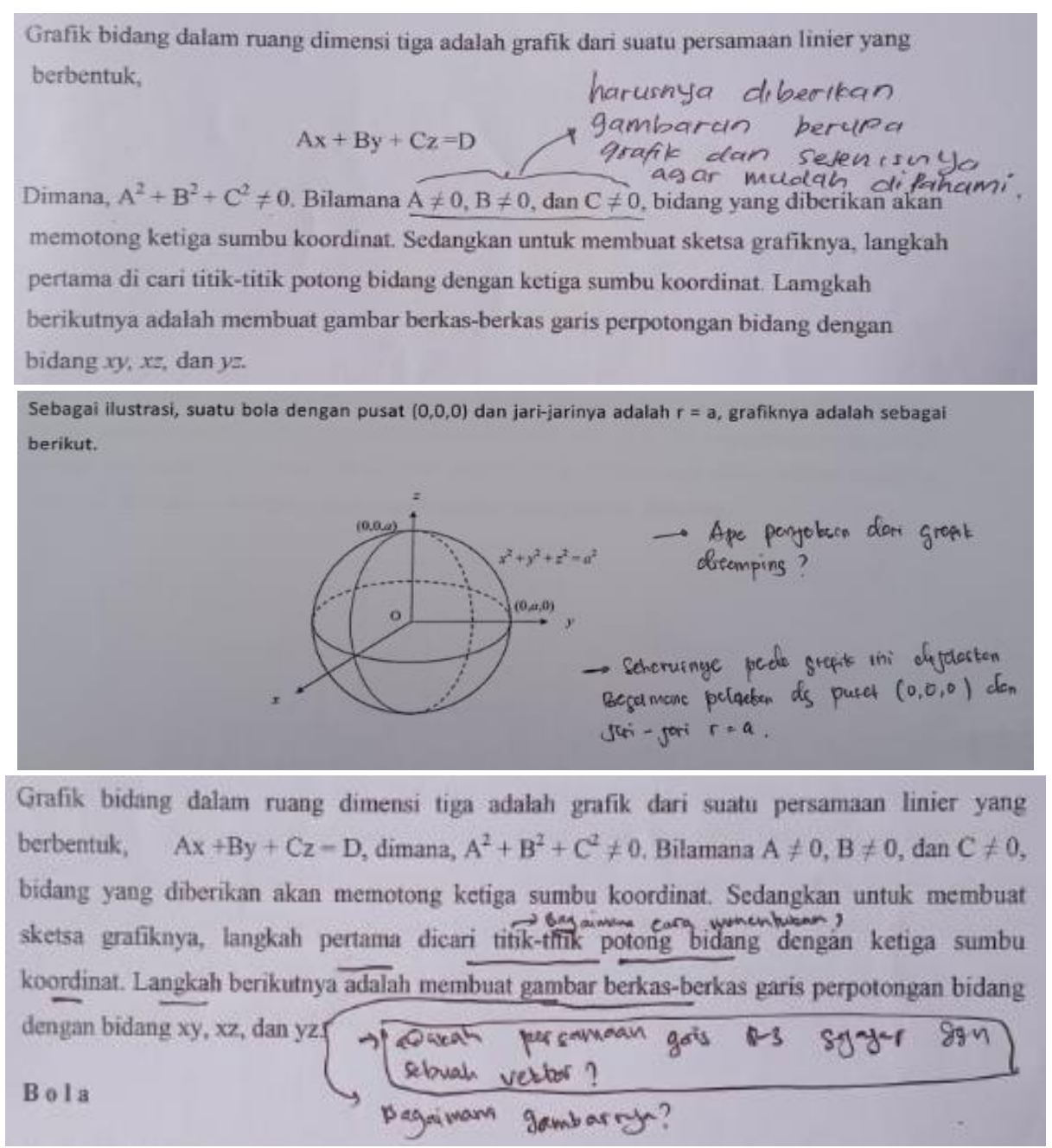

Gambar 2. Contoh catatan penting mahasiswa

Gambar 2 di atas memperlihatkan bahwa mahasiswa mengintepretasi dan menganalisis dan grafik sebagai bentuk visual dan informasi-informasi yang diterima dalam bantuk ide/gagasan/saran dan pertanyaan kritis yang didasarkan pengetahuan awal mahasiswa. Pada tingkatan ini mahasiswa berada pada level mengaplikasikan 
(applying) dimana mahasiswa memiliki kemampuan aplikatif dalam memahami konsep. Secara teori informasi yang diterima oleh Sensory Memory akan dipelajari dan diolah di Working Memory yang selanjutnya disimpan di Long Term Memory. Kapasitas Long Term Memory dalam menyimpan informasi dipengaruhi oleh muatan kognitif intrinsik, dan muatan kognitif ekstrinsik. muatan kognitif intrinsik dipengaruhi oleh pengetahuan awal mahasiswa, dan muatan kognitif ekstrinsik dipengaruhi oleh penyajian pembelajaran yang diterima mahasiswa (Salsabila, 2017).

Pada proses kognitif yang terakhir yaitu proses menguji atau mengevaluasi relevansi dan ketepatan pengetahuan, direpresentasikan dengan kemampuan mahasiswa dalam menjelaskan hubungan konseptual dan informasi yang faktual. Dalam proses kognitif ini digambarkan mahasiswa mampu membuat suatu pernyataan baru yang benar berdasarkan pada beberapa pernyataan yang kebenarannya telah dibuktikan atau diasumsikan sebelumnya. Proses ini diistilahkan sebagai proses penalaran (Reasoning). Berdasarkan analisis data kinerja mahasiswa, tidak terlihat adanya proses penalaran ini. Hanya ada satu mahasiswa yang membuat pernyataan berupa informasi faktual yang dihubungkan dengan konsep yang dipaparkan diperlihatkan pada gambar 3 berikut.

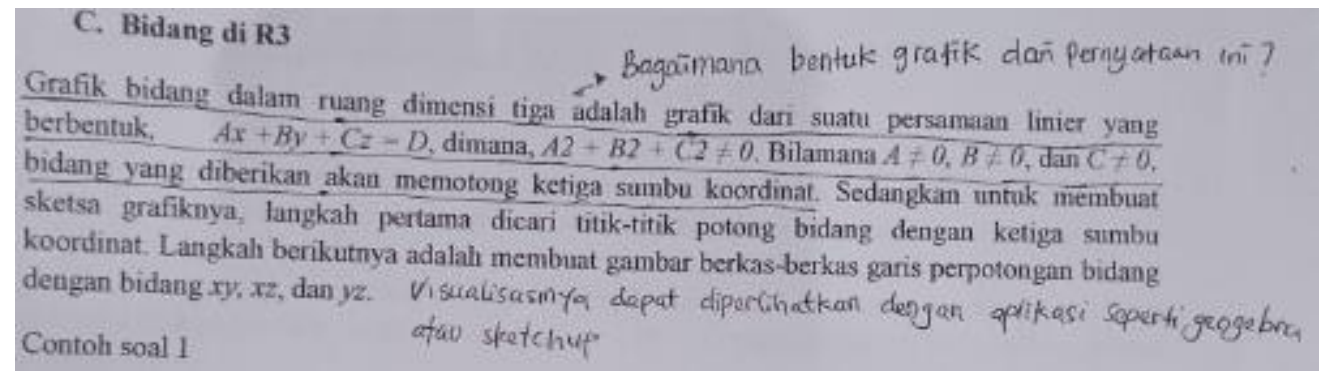

Gambar 3. Contoh catatan penting mahasiswa

Catatan yang dibuat mahasiswa pada Gambar 3 di atas berupa pernyataan yang mengarahkan atau menyarankan bahwa konsep yang disajikan secara faktual dapat digambarkan dengan menggunakan suatu aplikasi yaitu geogebra atau sketch up. Meskipun pernyataan ini belum bisa dikatakan sepenuhnya sebagai suatu proses penalaran tetapi, hal ini sudah menunjukkan bahwa mahasiswa mampu memikirkan hal faktual yang relevan dengan pengetahuan yang telah diperoleh.

\section{SIMPULAN DAN SARAN}

Berdasarkan paparan data hasil penelitian dapat disimpulkan bahwa mahasiswa semester V Prodi Pendidikan Matematika FSTT Universitas Pendidikan Mandalika pada tingkatan kognitif berada pada level tertinggi applying. Mahasiswa mampu menyerap informasi dan mengolahnya sampai pada batas mengaplikasikan. Mahasiswa belum mampu menganalisis, mengevaluasi dan mencipta. Pada proses kognitif mahasiswa mampu memperoleh informasi dan mentransformasi informasi yang diterima tetapi, belum mampu menguji dan mengevaluasi relevansi atau ketepatan pengetahuannya.

Berdasarkan temuan selama proses penelitian dapat disarankan bahwa pengetahuan awal mahasiswa menjadi hal penting yang sangat mempengaruhi seluruh proses kognitif mahasiswa. Sehingga sebagai dosen atau pengampu mata kuliah harus 
dapat mendesain pembelajaran dengan baik mulai dari apersepsi pembelajaran, pemilihan metode yang tepat sampai pada bentuk penyajian materi yang disampaikan.

\section{DAFTAR PUSTAKA}

Aprianti, D. (2017). Penerapan model gnt guide note taking (gnt) dalam meningkatkan hasil belajar Di Min Talang Empat Kabupaten Bengkulu Tengah. Al-Bahtsu, 2(1), 43-48.

Gusnita, Melisa, \& Delyana, H. (2021). Kemandirian belajar siswa melalui model pembelajaran kooperatif think pair square (TPSq). Jurnal BSIS, 3(2), 286-296.

Hidayat, O. R., \& Utami, Y. F. (2020). Pengaruh penerapan model pembelajaran Guided Note Taking (GNT) terhadap hasil belajar IPA siswa. BIOEDUSAINS: Jurnal Pendidikan Biologi Dan Sain, 3(1), 1-7. https://doi.org/https://doi.org/10.31539/bioedusains.v3i1.1108 PENGARUH

Kabunggul, Y., Pramita, D., Mandailina, V., Abdillah, Mahsup, \& Sirajuddin. (2020). Meningkatkan motivasi dan hasil belajar siswa melalui penerapan model pembelajaran team game tournament berbantuan media android. Pendekar: Jurnal Pendidikan Berkarakter, 3(2), 1-4.

http://journal.ummat.ac.id/index.php/pendekar/article/view/2804

Kosko, K. W., \& Wilkins, J. L. M. (2010). Mathematical communication and its relation to the frequency of manipulative use. International Electronic Journal of Mathematics Education, 5(2), 79-90. https://doi.org/10.29333/iejme/251

Kusmaniar. (2019). Peningkatan motivasi belajar siswa melalui model pembelajaran kooperatif tipe jigsaw. FITRA, 4(1), 50-62.

Lestari, I. D., Ekanara, B., \& Purwaningsih, D. E. (2021). Upaya meningkatkan kemampuan kognitif siswa kelas XI SMAN 4 kota serang melalui penerapan model pembelajaran kooperatif tipe jigsaw. Indonesian Journal of Educational Development, 1(4), 641-649. https://doi.org/10.5281/zenodo.4560738

Oktafiani, Z. (2017). Meningkatkan aktivitas dan kemampuan kognitif dengan model pembelajaran kooperatif tipe jigsaw pada siswa kelas X SMA Negeri 1 Wedung tahun pelajaran 2016/2017. JP3 (Jurnal Pendidikan Dan Profesi Pendidik, 3(1), 59-73.

Salsabila, N. H. (2017). Proses kognitif dalam pembelajaran bermakna. Konferensi Nasional Penelitian Matematika Dan Pembelajarannya II (KNPMP II) Universitas Muhammadiyah Surakarta, 18 Maret 201, Knpmp II, 434-443. http://hdl.handle.net/11617/8830

Sari, N., \& Suarni, N. (2020). Peningkatan hasil belajar kognitif melalui model pembelajaran kooperatif tipe numbered head together (NHT) tema perkalian dan pembagian pecahan. Jurnal Elementary (Kajian Teori Dan Hasil Penelitian Pendidikan Sekolah Dasar), 3(2), 92-96. https://unars.ac.id/ojs/index.php/pgsdunars/article/view/588 
Sutarto, S. (2017). Teori kognitif dan implikasinya dalam pembelajaran. Islamic Counseling: Jurnal Bimbingan Konseling Islam, 1(2), 1-26. https://doi.org/10.29240/jbk.v1i2.331

Syaharani, A. (2018). Pengaruh model pembelajaran kooperatif dan kemandirian belajar terhadap penguasaan konsep Biologi (Studi Kasus Siswa SMP Negeri 1 Kota Tangerang). ALFARISI: Jurnal Pendidikan MIPA, 1(1), 9-20. https://journal.lppmunindra.ac.id/index.php/alfarisi/article/view/2887

Utami, S. (2015). Peningkatan motivasi, kemandirian dan hasil belajar melalui pembelajaran kooperatif pada pembelajaran dasar SINYAL AUDI. Pendidikan Vokasi, 5(1), 55-73.

Yuntawati, \& Aziz, L. A. (2017). Problem posing setting kooperatif untuk meningkatkan kemampuan menyelesaikan masalah matematika siswa. Jurnal Kependidikan, 16(2), 180-191. 